\title{
CHALLENGING RELIGIOUS AUTHORITY The Emergence of Salafi Ustadhs in Indonesia ${ }^{1}$
}

\author{
Din Wahid \\ UIN Syarif Hidayatullah, Jakarta - Indonesia
}

\begin{abstract}
With Muslims as majority population, religious authority plays important roles in Indonesia. This paper tries to show the map of religious authority in Indonesia both in history and the recent development. The paper shows that, in the past, religious authority in Indonesia were possesed by the kyai and other traditional religious leaders. However, there is an emergence of the new religious elites in Indonesia, the muballigh, the dai and the last is the salafi ustadhs. In addition, this paper also discusses the contestation between the established power of religious authority and the the newly emerged salafi ustadh. Feeling threatened by the changging trend and the influence of the salaf, there are various responses from the existing authorities. The responses vary from discussion to violence. One example is the mubahathah held between Persis and Salafi. Through the event, both parties tried to contest and challenge each other's authority. Using religious arguments and using some religious symbols, both parties actually try to maintain their religious authority.
\end{abstract}

Keywords: Salafi, Persis, Kyai, religious authority.

\section{Introduction}

As charismatic leaders, the role of religious leaders (kyai, 'ulama , and muballigh) in Muslim community is central. Their charisma stems from their deep knowledge of religion and good conduct. Consequently, they are the persons whom the people obey, listen to

\footnotetext{
${ }^{1}$ The earlier version of this paper was presented at The $12^{\text {th }}$ Annual International Conference on Islamic Studies (AICIS), held by the Ministry of Religious Affairs and the State Institute of Islamic Studies (IAIN) Sunan Ampel, Surabaya, 5-8 November 2012.
} 
their advice, and imitate their conduct. Although their main expertise is religion, their role in community expands beyond this expertise. People usually come to them for a number of various purposes, ranging from family matters to social ones, from business affairs to politics. The government also benefits from them by asking their support for the government's program. Their support takes several forms, from issuing the fatwa to direct involvement in the program. On the other hand, the kyais and 'ulama also benefit from the government. They receive large amount of money from the government to support their activities, such as the development of their madrasahs and pesantrens.

Since the last decade of the twentieth century, Indonesia has witnessed the emergence of Salafi movement. Supported by the same global movement, this movement has produced Salafí leaders, wellknown as ustädhs. They graduated from the Salafī education institutions in Yemen and Saudi Arabia. Some of them are alumni of the Saudisponsored higher education, LIPIA (Institute of Islamic and Arabic Studies) in Jakarta. In addition to their activities in teaching the students in their pesantrens, these ustädhs actively hold religious teaching in public mosques, offices, or private houses. Their religious gatherings have attracted the followers, and thus they become new religious leaders, religious elite, who challenge the existing religious authorities: kyais, 'ulama', and religious leaders of mass organizations. The challenge of this group has been consciously sensed by the leaders of mass Muslim organizations, because of the conversion of some of their activists. Community responses to the Salafí movement are various, ranging from verbal to violent action. This article discusses how this new religious elite emerges and challenges the existing religious leaders.

\section{Religious Authority: Kyai, 'Ulamāand Ustädhs}

Kyai, ulamā and ustäd are religious elites who hold religious authority. Religious authority means "the right to impose rules which are deemed to be in consonance with the will of God." In Weberian context, it can be defined as "the right to impose obedience in the name of common values and rules of conduct, shared by those who exercise this authority and those who are submitted to it". ${ }^{2}$ Muslim

\footnotetext{
2 Marc Gaborieau, "Redefinition of Religious Authority among South Asian Muslims from 1919 to 1956", in Azyumardi Azra, Kees van Dijk, and Nico J.G. Kaptein (eds), Varieties of Religious Authority (Singapore and Leiden: Institute of Southeast Asian Studies (ISEAS), and International Institute for Asian Studies (IIAS), 2010), p. 1.
} 
community called this group differently. The Sundanese of West Java calls kyai as Ajengan, while the Acehnese calls this scholar as Teungku. ${ }^{3}$ They are the specialists in religious sciences, and are capable of giving guidance and advice to the people on religious matters and good conducts in line with religious injunctions. The term kyai is a title given by community to the scholars of Islam, who usually lead pesantren. ${ }^{4}$

Slightly different from kyai, ulama is a title given to scholars of Islam who do not lead pesantren. Literally, the term 'ulamá connotes the people with broad knowledge. The knowledge in this regard is universal, covering both secular and religious knowledge. However, this broad sense narrows to limited people, to those who possess good command of Islamic knowledge, particularly figh (Islamic law) and badith. 5 Thus, the term 'ulama denotes a wider coverage than the term kyai. However, these terms are used interchangeably. These titles, kyai, ulama $\bar{a}$, and ustadh, are given by the community. They are given after deliberate consideration based not only on the depth of knowledge of the persons, but also on their ethics and good conduct. ${ }^{6}$

Scholars hold different opinions concerning the position between kyai and 'ulamā; who is superior between the two. Hiroko Horikoshi maintains that kyai is higher than 'ulama. He argues that a kyai is more capable than 'ulama in exercising ijtibăd (free reasoning), while the 'ulamā do not. For him, 'ulamā holds taqlìd (blind imitation) to the opinions of earlier 'ulamá. Kyai is also perceived more charismatic than the 'ulama' in the eyes of community. 'Ulamā represent themselves as religious officials (religious functionaries). In this regard, Horikoshi said that 'Ulama hold this function in religious institutions, such as madrasah and pesantren". ${ }^{7}$ The different titles of kyai and "ulama lie on the social status and influence of these two figures in the community. On the contrary, van Bruinessen views that the position of 'ulama $\bar{a}^{-}$is

3 M. Iskandar, et.al., Peranan Elit Agama pada Masa Revolusi Kemerdekaan Indonesia (Jakarta: Departemen Pendidikan Nasional, 2007).

${ }^{4}$ Zamaksyari Dhofier, Tradisi Pesantren (Jakarta: LP3ES, 1982), p. 55.

5 Azyumardi Azra, "Biografi Sosial-Intelektual Ulama Perempuan: Pemberdayaan Historiografi," in Jajat Burhanudin (ed.), Ulama Perempuan Indonesia (Jakarta: Gramedia and PPIM UIN Jakarta, 2002), p. xxx.

${ }^{6}$ Azra, "Biografi Sosial-Intelektual Ulama Perempuan," p. xxxi.

${ }^{7}$ Horikoshi, Kyai dan Perubahan Sosial (Jakarta: Perhimpunan Pengembangan Pesantren dan Masyarakat (P3M), 1987), pp. 1-3. 
higher than that of kyai. This evaluation is based on a kyais acknowledgment whom he interviewed. Although van Bruinessen regarded him as an 'ulamá, the kyai felt that he had not reached the level of 'ulamä; he was still in the level of kyai.

In practice, the title of kyai is also given to the chairperson of mass Muslim organizations, such as the Nahdlatul Ulama (NU) and Muhammadiyah. In the NU community, some leading figures such as Muchith Muzadi, are called kyai although they do not head pesantren. A similar tradition occurs in Muhammadiyah. Since its foundation in 1912, the chairpersons of Muhammadiyah were called kyai. To give example, Abdul Razak Fachruddin (chairman of Muhammadiyah from 1971 to 1985), and his successor, Azhar Basyir (chairman of Muhammadiyah from 1995 to 1998) are called kyai even though they did not lead the pesantren. This title, however, ended in the era of Azhar Basyir. After Basyir, Muhammadiyah was led by Muslim intellectuals: Amien Rais (from 1995 to 1998), Syafi'i Maarif (from 1998 to 2005), and Sirojuddin Syamsuddin (from 2005 to date). Rather than a representation of traditional kyais, these leaders are Muslim scholars who are graduated from American universities in social sciences; Rais is graduated in political sciences from the University of Chicago, Maarif is graduated in history of Political Islam from the University of Chicago, while Syamsudin is graduated in political Islam from University of California at Los Angeles. 9 'They indeed hold good understanding of religion, because they went to Islamic education institution before their study abroad. Din Syamsuddin, for example, went to a famous modern pesantren, Darussalam, Gontor, East Java. Moreover, he graduated in comparative study of religions, at the State Institute of Islamic Studies (IAIN, now UIN) Jakarta. Thus, since the last decade, Muhammadiyah has been led by Muslim intellectuals, or 'ulamā in a broader sense.

Besides kyai and 'ulamā, the term ustädh and muballigh are commonplace to call a man of religion. The term ustädh connotes the

\footnotetext{
${ }^{8}$ Martin van Bruinessen, Rakyat Kecil, Islam dan Politik (Yogyakarta: Bentang Budaya, 1998), pp. 167-168.

${ }^{9}$ On brief account of these Muhammadiyah leaders, on Amien Rais, see, http://www.muhammadiyah.or.id/id/content-167-det-prof-dr-h-amien-rais.html; on Syafii Maarif, see, http://www.muhammadiyah.or.id/id/content-168-det-prof-dr-ahmad-safii-maarif.html, and on Sirojuddin Syamsuddin, see, http://www.muhammadiyah.or.id/id/content-169-det-prof-dr-h-m-din-syamsuddin.html, accessed on January 2, 2012.
} 
teacher of religious knowledge. The teachers of pesantren, regardless the subjects taught, are called ustädh by santris and the surrounding community. In practice, a person who frequently delivers religious lesson in mosques is also called ustädh. The community often called this type of religious man as muballigh (preacher). In addition to religious lessons taking place in mosques, offices, and houses, ustäds and muballigh often deliver Friday sermons. In many cases, ustäds and muballighs get income in form of fee from this activity. In fact, some professional ustadhs and muballighs earn a great amount of money from this activity. Concerning these titles, it is worth to mention here that, unlike the heads of traditional pesantren of NU who are called kyai, leaders of Muhammadiyah pesantren are simply called ustädh. The same call is found in another reformist organization, the Persatuan Islam (Persis). The leaders of this puritan group are called ustädhs, and leaders of Persis' pesantren are simply called ustädh.

Kyai's role in the community is very central. People come to this group of religious elite for different purposes: asking religious guidance, acquiring solution for family problems, economic consultation and even asking for political support. In many occasions, some people consult kyai and ask his advice before commencing their business and marriage. Here, Geertz mentions the role of kyai in the community is like a cultural broker. He argues that as a person with deep knowledge of religion, kyai's role is to transform the universal doctrines and values of religion as prescribed in the Qur'an, hadith, and books of the Islamic law in different madhhabs (schools of Islamic law), and adjust them into local practices. In this regard, the kyai interprets the abstract, universal and systematic doctrines of Islam in the context of local beliefs and traditions. It is the kyai, Geertz claims, who determines whether or not local practices are Islamic. ${ }^{10}$ Many ordinary Muslims even believe that kyai has supra-natural power that enables him to see evil spirits and to forecast future fortune. In congruent with animistic belief of the villagers, some kyai acted as dukun curing some diseases. Observing this phenomenon, Geertz concludes that "the kijaji [kyai] thus brings together the general moral doctrines of Islam and the specific animistic notions of local tradition, the fragmented, barely conceptualized, practical religion of the

${ }^{10}$ Clifford Geertz, "The Javanese Kijaji: The Changing Role of a Cultural Broker," Comparative Studies in Society and History, Vol. 2, No. 2 (January 1960), p. 236. 
ordinary peasant..."11 A similar assessment is given by Horikoshi. Based on his research on the role of kyai in Garut, West Java, he observes that kyai plays a significant role in preserving the traditional practices, filtering negative values of modernizations, and becoming the agent of change, such as providing the community with educational and economic opportunities. ${ }^{12}$ In short, kyai plays as a key agent of change, of modernization, who actively introduces the modern values to the villagers. ${ }^{13}$

Along with the changes of social and political conditions of postIndependence Indonesia, the mediatory role of kyai shifts from bridging between what is called a "Meccan" universal notions of Islam and "Javanese" beliefs and practices to linking between Jakarta and the village. This transformation occurred when the idea of state nation emerged and needed to be communicated and understood by the villagers. As a modern nation needs political engagement of all citizens via, among others, their participation in political parties, many kyais are involved in supporting the traditionalist Islamic party, the Nahdlatul Ulama. Through this party, as the 'owners" of the ummab in the level of grassroots, kyais are active in mobilizing the ummah via public gatherings. In these occasions, in addition to giving religious guidance, kyais tried to translate modern ideas of development into religious terminologies, and talk to the ummah in local languages. Thus, Geertz concludes that as a cultural broker, kyai has shifted from a broker for Islamic civilization to a broker for national government. ${ }^{14}$

Regarding these titles, Salaj $\bar{i}$ teachers are not called kyais, but ustädh. The leaders of Salafi pesantrens are simply called ustädh or mudir al-ma'bad (director of pesantren), to denote the position of the teacher. This title reflects equality among Salafis. It is common to find that santris of Salafi pesantrens talked with the mudir freely without nervousness. During my fieldwork in pesantren Al-sunnah in Cirebon, for example, I frequently witnessed Thaharah, the then mudir, sitting in mosque's corridor talking with santris. Similarly, this scene also occurs in the Salafi $\bar{i}$ religious gatherings: some followers move closer to Salaf $\bar{i}$ teachers after religious gatherings in mosques. They ask the teachers

\footnotetext{
11 Ibid., pp. 238-239.

12 Horikoshi, Kyai dan Perubahan Sosial, p. 6.

13 Ibid., p. 5.

${ }^{14}$ Geertz, “The Javanese Kijaji”, p. 247.
} 
about religious matters which have not been answered during the session. This condition, equality, seems to be attractive for a new adherent or sympathizer of Salafi $\bar{i}$ movement. A managerial staff at the STAI Ali ibn Abi Thalib in Surabaya, East Java, for example, told that one of his interests in joining Salafism is equality that is shown by Salafi teachers. He compared between kyais of traditional pesantrens of the Nahdlatul Ulama and the mudirs of Salafi pesantrens. While the santris of Salafi pesantren can approach the mudir easily, the santris of the traditional pesantrens respect their kyais excessively, expressed by several acts such as kissing hand (taqbi), preparing sendal when the kyai wants to go out from the mosque, and giving massage to the kyai before teaching. In addition to honor, these attitudes aim at acquiring the berkah (Ar., barakkah means God's blessing) from the kyai. The students believe that by respecting and serving the kyai, they will receive God's blessing through them.

The santris attitudes towards their kyai are rooted in traditional doctrine of the student's behavior towards the teacher in the kitab kuning commonly taught in the pesantren community, the Ta'lim alMuta'allim Täiq al-Ta'allum ${ }^{15}$ of Burhān al-Islām al-Zarnüji. This work deals with a number of instructions and methods of learning. The work is divided into 13 chapters, including the nature and merit of knowledge, the intention of study, the choice of subject matters of knowledge, the teachers, the colleague, and the permanent association; respecting the knowledge and those who possesses it. Of most important subject of this work is pupil's attitude towards his teacher. According to the work, a student should fully respect his teacher. A student is not allowed to walk in front the teacher; not to seat on teacher's chair; not to begin talking with the teacher without his permission; not to talk much with the teacher without his consent. ${ }^{16}$ In addition, the students have to respect the teacher's relatives and colleagues. For example, the students have to stand when a son of teacher comes to show their respect to the teacher. ${ }^{17}$ Based on these

15 Imam Burhan al-Islam al-Zarnuji, Ta'lim al-Muta'allim Tariq al-Ta'allum (Surabaya: Benkul Indah, n.d.). The work has been translated into English by G.E. Von Grunebaum and Theodora M. Abel. See, Az-Zarnuji, Instruction of the Student: The Method of Leaning (New York: King's Crown Press, 1947).

16 Ibid., pp. 16-17.

17 Ibid., p. 17. 
teachings, students of traditional pesantrens fully respect their teachers. They believe that respecting the kyai and teachers will result in God's blessing.

Sociologically, there is stratification among Salafi ustädh. Thus, here we can identify some prominent ustädhs among Salafī groups, whom we can classify them into senior ustähss. Within the so-called "Yemeni" Salafis in Indonesia, we can mention Muhammad as-Sewed and Luqman Ba'abduh as senior ustädhs. The two figures are regarded as their leaders replacing Ja'far Umar Thalib. As-Sewed currently heads two pesantrens, Dhiyā' al-Sunnah in Cirebon, West Java, and al-Anshār in Sleman, Yogyakarta. Meanwhile, Ba'abduh is currently the director of pesantren Salafiya in Jember, East Java. Before directing this pesantren, he studied with shaykh Muqbil al-Wadi'i in his institution, Dār alHadith, Dammaj, Yemen. There are indeed some other Salafi $\bar{i}$ teachers in the second level, such as Afifuddin of Sidayu, Gresik, and Abdul Mu'thi of Yogyakarta. In the other group, the so-called haraki Salafi, more prominent figures are found. Included in these leading ustādhs are Abdul Qadir Jawwas of Bogor, West Java, Abdul Hakim Abdat of Jakarta, Abu Nida of Yogyakarta, Abdurrahman al-Tamimi of Surabaya, and Ahmas Faiz Asifuddin of Solo. Both Jawwas and Abdul Hakim studied Salafism at the Institute of Arabic and Islamic Studies (LIPIA), Jakarta, and currently teach at pesantren Minhāj al-Sunnah in Bogor, West Java. Meanwhile, Abu Nida and Asifuddin are graduated from Jāmi’a Imām Muhammad ibn Su'ūd, Riyadh. Asifuddin currently heads large Salafi pesantren Imam Bukhari in Solo, while Abu Nida heads the Bin Baz Islamic center in Yogyakarta. In the lower level, some figures emerge, including Abu Qatadah of Tasikmalaya, Abu Haidar of Bandung, Mubarak Bamualim of Surabaya.

\section{Salafi Ustāds: Challenging Religious Authority}

The emergence of Salafi teachers challenges the existing of religious authorities. Salafis challenge both traditional and reformist religious leaders: kyai, ulama and muballighs. The emergence of Salafism has caused opposition from villagers and local religious leaders as well. To show this challenge, this article will describe in this part the mubähathah (discussion, dialog) between Salafis and leaders of Persatuan Islam (Persis). In this dialog forum, each party poses and examines its religious arguments before public. 
The case of mubahathah shows how Salafis challenge the religious authorities of Persatuan Islam (Persis), a purist and reformist organization. The mubāhathah entitled "Mengungkap Gerakan Salafy di Indonesia [Discovering Salafi $i$ Movement in Indonesia]" was conducted on 27 March 2007 in Bandung, West Java. The initiative of this dialog emerged from the head of Persis, West Java region. It was attended by prominent figures of Persis, including Siddiq Amien (chairman), Aceng Zakaria (the then head of Pesantren Persis in Garut, West Java), Usman Sholehuddin, head of Dewan Hisbah Persis, and Maman Abdurrahman. In addition to these leading figures of persis, the forum was also attended by delegations of Persis from all districts in West Java. The other party, the Salafis, is represented by Abdul Hakim Abdat (Jakarta) and Abu Qatadah (director of pesantren Ihyaus Sunnah, Tasikmalaya, West Java). Other Salafi figures, such as Tonari (Cirebon), Yunus Anis and Ayip Saefuddin were also present. During the discussion and dialog, Salafis and Persis discussed arguments and examined the dalil of the necessity in following the Salaf manhaj.

The discussion was started by a welcoming speech of the committee, and a brief speech of the head of Persis, West Java region. Following these speeches, Siddiq Amien, as a keynote speaker, presented his article on "Fenomena Gerakan Dakwah Salafy di Indonesia dan Menimbang Argumentasi Manhaj al-Salaf al-Saleh sebagai Dasar Ketiga sesudah al-Qur'an dan al-Sunnah" [Phenomenon of Salafi Da'wah Movement in Indonesia and Examination of arguments of Salaf Manhaj as the Third Source after the Qur'an and Sunnah]. In his presentation, Amien highlighted some essential aspects of the Salafi $\bar{i}$ movement in the country. In the first part of his presentation, he discussed the definition of Salafism. On this issue, he elaborated the meaning of "Salaf" and its derivatives. He explained that "Salaf" literally means "the predecessor", and the "Salaf al-Salib" denotes the first three generations of Muslims, consisting of the Companions, the Followers, and the Followers of Followers. Meanwhile, Salaji connotes a person who follows the path of Salaf. In this point, Amien, as a representative of Persis, did not differ from the Salafis in defining Salafism. Amien then complemented his presentation with his observation on the rise of Salafis movements in Indonesia. For him, the Salafi doctrines had inspired some religious movements in the country. The Wahhabi movement inspired the Paderi movement in Minangkabau, West Sumatera, in the $19^{\text {th }}$ century. In the $20^{\text {th }}$ century, 
Salafi ideas influenced the birth of a number of reformist religious movements: the Jami'at Khayr in 1905 in Jakarta, al-Irsyad in 1913 in Jakarta, Muhammadiyah in 1912 in Yogyakarta, and Persatuan Islam in 1923 in Bandung. With a different emphasis, these organizations call on Muslim for the return the Qur'an and Sunnah; support the jibäd and ijtibäd; and fighting against bid'ah, khurafat, taqlìd; through various methods of da'wah, including education, preaching and publications. In Amien's observation, all these organizations are Salafis, because they follow the path of al-Salaf.

The second issue highlighted by Amien is fragmentation of current Salafi movement in Indonesia. Quoting the work of $\mathrm{Abu}$ Abdurrahman al-Thalibi, Dakwah Salafiyah Dakwah Bijak,18 Amien explored Salafis" fragmentation into "Yemeni" and "haraki" Salafis. The first faction refers to former Laskar Jihad activists under the leadership of Ja'far Umar Thalib, and the followers of shaykh Muqbil al-Wadi'i of Yemen, and shaykh Rabi 'bin Hādi al-Madkhali of Saudi, while the latter is associated with the Ihyā' al-Turāth al-Islāmī and alMuntad̄ā al-Islāmī. While the first group of Salafis refutes the haraki method in da'wah, the latter maintains that the baraki method is needed in the application of da'wab in this modern era. Furthermore, Amien also mentioned the existence of individual conflict between Salafis.

The last problem roused by Amien in his speech was the nature of difference between the Salaf, the first three generations of Muslim. Amien agreed with Salafis that, besides the prophet, Muslims must take into account the examples and opinions of the Salaf on religious matters. However, it was the fact that the Salaf themselves also differed in a number of issues. One example is how Abu Bakr al-Siddiq and 'Umar bin Khattāb on the one hand and 'Uthmān bin 'Affän on the on the other hand have different views on the issue of ädhan (call for prayer) of the Friday prayer. Following the prophet, the first two caliphs implemented one ādhān before the prayer, while the third caliph added one more ādhān, and thus, there were two àdhān during the reign of 'Uthmān. Taking this case as example, Amin questioned "which Salafis Muslim should be followed: Abū Bakr and 'Umar, or 'Uthmān"? According to Persis, the rationale of 'Uthmān was clear; as

18 Abu Abdirrahman al-Thalibi, Dakwah Salafiyah Dakwah Bijak (Jakarta: Hujjah Press, 2007). 
the Muslim's territory expanded, Muslims became more widespread and, therefore one more ādhān was added to signify the coming of prayer time. Thus, following this example, Persis contended that the Salaf exercised a rational thinking. Taking this difference into account, together with the prophet's last speech on the necessity of maintaining the two sources of Islam, the Qur'an and sunnah, Amien concluded that Persis discovers no clear sound argument on the obligation of Muslims to follow the Salafs manhaj (path) as advocated by Salafis.

Following the keynote speech by the chairman of Persis was Salafis' presentation. There were two Salafis presenting their speeches: Abdul Hakim Abdat, and Abu Qatadah. Abdat is a senior Salafi ustädh, while Abu Qatadah is a more junior ustädh. Both ustädhs are of the leading Salafis who frequently visit a number of cities to preach Salafism. Abdat took the first chance. The focus of his presentation was the religious arguments on the obligation for Muslims to follow the Salaf manhaj in their religiosity (thought and conduct). Before discussing this issue, he first took this opportunity to refute analysis and remarks of the previous speaker, Siddiq Amien, dealing with the frictions among Indonesia's Salafi, and the absence of a clear and sound argument of the necessity of imitating the Salaf. On the first issue, Abdat denied the frictions among Indonesia's Salafis into Yemeni and Haraki. According to him, this fraction is only an opinion, and issue far from the reality. He claimed that Salafis are monolithic and do not recognize the fractions. In this regard, Abdat contended that the analysis must be applied to the manbaj, and not to individuals. On the second issue, Abdat maintained that Persis' incapability to find a clear and sound argument on Muslims' obligation to follow the Salafi manbaj does not denote the absence of the argument. This, according to Abdat, might be caused by the fact that Persis has not observed the dalil. Therefore, Abdat took this opportunity to present a number of religious arguments.

These religious arguments occupied the subsequent talk of Abdat. He elaborated arguments on the obligation for Muslims to follow the Salafi manhaj from the Qur'an, and hadith. He presented five dalils from the Qur'anic verses: 9:100; 9:119; 12:108; 2:136-137; 1:6. Because of the limit of time available, he presented only the first two arguments: 9:100, and 9:119. The first verse, 9:100, reads as follows:

The vanguard (of Islam)- the first of those who forsook (their homes) and of those who gave them aid, and (also) 
those who follow them in (all) good deeds,- well- pleased is Allah with them, as are they with Him: for them hath $\mathrm{He}$ prepared Gardens under which rivers flow, to dwell therein for ever: that is the supreme triumph.

Abdat argued that, as explicitly mentioned in the verse, the muhäjirun (emigrants) and anșär (helpers) were pleased by God. God's please men that God loves their deeds and actions. According to Abdat, the verse implies an order from God to the Muslims to follows the companions in order to acquire God's satisfaction. This order emerges in the form of khabar (news), not in form of ordinary order.

The second verse, 9:119, reads as follows:

"O, ye who believe! Fear Allah and be with those who are truthful."

According to Abdat, the term al-sadiqin (truthful) refers to the prophet's companions. Again, according to Abdat, this verse implies an order for Muslims to imitate the companions. In addition to Qur'anic verses, Abdat mentioned a famous hadith telling that best three generations of Muslims: the Companions, the followers and the followers of followers. Relying on these dalils, Abdat concluded that it is obligatory for Muslims to follow the Salaf manhaj is obligatory for Muslims.

The second Salafi speaker was Abu Qatadah. Commencing this talk, he acknowledged humbly that he was an activist of Persis; he went to Persis pesantren for seven years before his conversion to Salafism. His talk focused on three issues: the sources of Islamic doctrines, divergent opinions of the companions, and the possibility or the potential of a person being deviant from the truth for not following the Salaf manhaj. Concerning the first issue, he explained that the sources of Islamic doctrines were the Qur'an, hadith, sound ijmä, (Consensus), and sound qiyass (analogy). On the second issue, the speaker acknowledged that the Companions had differed in a number of religious issues. Responding to these differences, Abu Qatadah maintained that Muslims can follow one of these opinions, but they are not allowed to add another opinion. On the third issue, Abu Qatadah argued that Muslim may fall into a mistake if he or she follows the Qur'an and hadith only. To strengthen his argument, Abu Qatadah recalled the history of Islam and take example of the case of assassination of 'A $\overline{l i}$ bin Abi Talib, the fourth caliph, by Ibn Muljam, 
an adherent of khawarij. Abu Qutadah told the story on how Ibn Muljam, when murdered the caliph, read the Qur'anic verse 5:44, which reads: "If any do fail to judge by (the light of) what Allah hath revealed, they are unbelievers." Referring to this fact, Abu Qatadah posed an essential and intriguing question: "Look at this case! How did the murderer read the Qur'an when he murdered the caliph?" Based on the case, he argued that the Qur'an and hadith alone are insufficient as the sources of Islam. Muslim must follow the Salaf manhaj in understanding these sources. Furthermore, he argued that all deviating sects, such as Khawārijite, Mu'tazilate and Shi'ite, complemented their arguments with Qur'anic verses and hadiths, but they interpreted these two sources in accordance with their reasonings.

The next session of the meeting was more interesting than the previous one since it provided discussion, dialog, and debate between Salafis and leading figures of Persis. The mostly asked question by the participants is question challengging the Salafis' claim that the Salafi manhaj was the true one. Maman Abddurahman, one of chairpersons of central board of Persis, posed question on whether Salafism is a method of thought or a name of group. If it is a method of thought, according to Abdurrahman, many Muslim thinkers, such as Muhammad Abduh, advocated the Salaf method. Concerning this issue, Abdurrahman argued that a number of Muslim organizations, such as al-Irsyad, Muhammadiyah and Persis, have adopted the Salaf method. In his opinion, the core spirit of the Salaf method is the reform movement including purification of aqidah (Islamic faith), purification of 'ibädah (rituals) and reform of mu'amalah (social interactions). Viewed from this perspective, Persis is also Salaf. If Salafism is a way of thought, Abdurrahman continued, why a group of Muslims claims to be the true Salaf. Another delegation from Tasikmalaya, Yuyu Wahyu, raised an almost similar question challenging the validity of Salafis' arguments. In direct manner, he asked: "Who are the Salaf"? Are Muhammad 'Abduh and his disciple, Rashid Rida, Salaf? He challenged the Salafis' arguments of the obligation of following the Salaf manhaj. According to him, the prophet advised Muslims to hold to the two sources only, the Qur'an and hadith. The prophet also believed that Muslims will not deviate from the true Islam when they follow these fundamental sources. In order to understand the two sources, Muslims must learn some methodological approaches, which in turn, will result in a number of laws. However, Wahyu added, Persis examines not only 
the products (thought and laws), but also the process (methods) and rationale of the products. This is in line with a maxim of Islamic legal theory, "the law depends on the availability of reason" (al-bukm yadur ma a al- 'illab wujūdan wa ‘adaman). The third participant, Zae Nandang, asked the speakers about the different opinions among the companions. When the companions differed each other on one matter, Nandang asked, whom Muslim must follow.

Responding to these questions, Abdat, the first Salafi speaker, replied that what he delivered was the Salafi manhaj as a method of thought and a way of religious life, and not the matters of figh in which the Salaf had differed in a number of issues. Abdat contended that the Salaf had agreed on essential teachings of Islam. They believed in God's punishment in the graves after the death, in the God's predestination, in God's occupation on His Chair ('Arsh), in God's Face and Hand, which are different from those of human, and in eternality (qadim) of the Qur'an. Abdat argued that the Salaf did not differ on these matters. On the need of following the Salafi manhaj, Abdat argued that the Qur'an and hadith are true (haq). However, he continued, not all the people arguing with the Qur'anic verses and prophetic traditions are true. Again, he mentioned a number of Muslim groups as examples.

One example is the Mu'tazilite, who reject some hadith because they perceived that these badiths contradict the Qur'an. According to Abdat, the Mu'tazilite and the Muslim philosophers referred to the Qur'an and hadith to support their thought, but they interpreted them merely in line with their ratio and logic. Consequently, they deviated from the true Islam. In order to avoid the same mistake, Abdat argued, following the Salaf manhaj is necessary in understanding the Qur'an and hadith. Thus, the phrase "the return to the Qur'an and hadith" in the salafi slogan, as advocated by a number of reformist Muslim organizations, must be accomplished by "with understanding of the Salaf". Meanwhile, in his reply, Abu Qatadah highlighted the characteristics of the Salaf. Referring to Yahyā 'Abd al-Mu'in, he mentioned a number of beliefs of abl al-sunna. These include the belief in the pre-destination; giving precedence to Abū Bakr and 'Umar bin Khattāb in faith and caliphate; the belief in the punishment in the grave; and the belief in the Day of Resurrection. Moreover, he mentioned a number of Salafi methods in concluding the laws (istidlä). First, the return to the Qur'an and hadith; second, understanding the 
Qur'an and hadith in line with the Salaf manhaj; third, preferring the texts (nass) than ratio ('aq); fourth, returning the mutashabib texts (allegoric texts that have more than one and uncertain meanings) to the mubkam texts (texts that have accurate and precise meanings); and the last, reconciling the arguments when the dalils differ. Based on this ground, Abu Qatadah contended that each individual, group or organization must do introspection on whther or not they are Salafi.

The discussion continued to the second term providing opportunities for the participant to have a question and answer session. There were four participants raising questions in this term. Almost all of them asked, and at the same time challenge, the validity of Salafis arguments on the necessity for following the Salaf manhaj. They also questioned the speakers about whom they must follow when the Salaf differ in a number of issues. Uus, for example, severely criticized Salafis for their insistence in following the Salaf manhaj. He argued with a widely accepted hadith telling a dialog between the prophet and Mu àdh bin Jabal before the prophet sent him to Yemen. The prophet was reported to have asked his messenger on the sources of religious matters. Ibn Jabal replied that he would rely on the Book of God and the Sunnah. If he could not find in these two fundamental sources, he would exercise ijtihäd with his ratio (ajtabid bi ra'yl), and the prophet agreed with his answers. Relying on this story, as continued arguing that the hadith does not tell Muslims to follow the opinions of the companions.

Encountering these questions, the Salafis remained in their position. Abdat, for example, repeatedly maintained that the dialog should be focused on the Salaf manbaj as a method of thought and conduct in religious matters. For him, the differences of opinions between the Salaf is not an issue and hence is also not needed to be questioned, since they appeared in the particularity and disputed matters (juz'iyyat and kbiläfiyät), and not in the essential doctrines of Islam, the aqida.

It appeared that during the mubahhatha, Salafis and Persis disputed on several aspects. On the one hand, since the beginning, Persis raised the questions of the differences among the companions of the prophet on a number of issues. Through these differences, Persis contended that Muslims should grasp the spirit and the elanvital of the difference, and not the texts, in order to cope with modern demands. On the other hand, Salafis tried to avoid discussing the differences between 
the Salaf. Rather, they sought similarities among them and tried to put emphasize on this. They argued that eventhough they (the salaf) differ in many issue, they agree in essential doctrines.

From the presentation and the dialogue, it is quite clear that both parties, salafi $i$ and persis, agreed that the Salafi manhaj is a method of thought in concluding Islamic law. In addition, both of the two organisations, represented by the presentators, also agreed that the Salaf were the best generations of the Muslim community since they are considered as the people who understand the religion best after the prophet. However, Salafis and Persis disputed in whether it is obligatory for Muslims to follow the Salaf manhaj. As evident in the Salafis' arguments, this obligation is inferred and indirectly ordered by the Qur'anic verses and hadith. God's satisfaction with the Salaf, for example, is understood and interpreted by Salafis as an inferred order for Muslim to follow the Salaf. Similarly, the widely accepted hadith on the best three generations of Muslim community is considered as an indirect instruction from the prophet to follow the Salaf manhaj. This rationale is rejected by Persis. According to Persis, there is no clear and sound religious argument from the Qur'an and hadith that oblige Muslims to follow the Salaf manhaj. Two famous hadiths are cited in this matter. The first is the hadith telling the last advise of prophet for Muslims to hold on to the Book of God and Sunnah. The second is the hadith of Mu'ādh bin Jabal. These hadiths, in Persis arguments, do not request Muslims to follow the Salaf manhaj.

Besides the content of the debate, another important thing evident from this event is to see clearly how Salafis and Persis examine their religious arguments, challenging each other, and contesting their religious authority. Here, the effort to establish their religious authority was not only seenfrom the Salafis' religious arguments, but also in their way of delivering and further defending their argument. During the dialogue, Abu Qatadah always read Arabic texts and then translating it into Bahasa Indonesia. Although his translation was exactly the same as the Arabic text, he felt the need to expose his argument first in Arabic, and then followed by its translation. With this method, he wanted to show the audience that his Arabic is excellent and he is authoritative in religious affairs. In addition, he also wore turban during the dialogue. For many people, turban symbolizes piety and certain degree of religious knowledge. Through this dialogue, each party, 
especially the Salafis, seemed to try maintaining their religious authority before their adherents.

From the case illustration above, it is interesting to observe the shift of religious authority in Indonesia. The traditional religious authorities (kyai and 'ulamāa) have been recently challenged by the newly emerging and popular muballighs (preacher), and $d \vec{a} \cdot \vec{i}$ (preacher), such as Arifin Ilham and Abdullah Gymnastyar (well-known as 'Aa Gym). Supported by electronic media, particularly the national television channel, such as TV One, Metro TV, Surya Citra Television (SCTV), these young figures have attracted wide range of Muslims accross indonesia. This phenomenon can be observed from the participants attending the religious lessons delivered by these figures. The "Majelis Zikir" of Arifin Ilham, for example, was attended by hundreds of Muslims. The participants, mostly women, wear the white long dresses and chanted dhikr (special formula to remember God). What is interesting from the Majelis Zikir is that many participants cry during the pengajian. In addition to the dhiker, the content of the lesson delivered by Ilham is simple yet important matters in Islamic teaching such as prayers and other daily duties for the Muslims. ${ }^{19}$ Another famous preacher whom also adored by women is Abdullah Gymnastyar from Bandung, West Java. He manages religious programs adopting the name of "Manajemen Qalbu" (Heart Management). Like Arifin Ilham, Gymnastyar's sermons were also attended by thousands of Muslims, mostly women. His fame significantly deteriorated after he took a second wife. This deterioration, according to Hoesterey, due to the fact that Gymnastyar's authority does not stem from his deep knowledge of Islam, but from his image of an ideal man and at the same time an ideal husband. Before his fans, Aa Gym is represented as a good husband for his wife, and a good father for his children. Thus, when Aa Gym took the second wife, he broke his image. ${ }^{20}$

In addition to these individuals and independent preachers, Muhammadiyah and Nahdlatul Ulama also have faced the challenges from mass organizations, namely Hizbut Tahrir Indonesia (HTI) and

19 Andree Feillard, "From Handling Water in a Glass to Coping with Ocean: Shift in Religious Authority in Indonesi," in Azra, van Dijk, and Kaptein (eds), Varieties of Religious Authority, p. 168.

${ }^{20}$ James B. Hoesterey, "Marketing Morality: The Rise, Fall and Rebranding of Aa Gym," in Greg Fealy and Sally White, Expressing Islam: Religious Life and Politics in Indonesia (Singapore: ISEAS, 2008), pp. 95-112. 
Justice Prosperity Party (PKS). As a party of da'wah, PKS, which attracts many fresh graduates of the Middle Eastern universities, often produces its religious "fatw $\bar{a}$ ". In 2005, for example, PKS declared publicly that the celebration of $\overline{\mathcal{I}} d$ al- $A d \bar{d} \bar{a}$ is one day earlier than the official day decided by the government. ${ }^{21}$

\section{Conclusion}

The emergence of Salafi movement raises different responses from Muslim community. The responses vary from verbal to physical gestures; from intellectual to violence. The case of Mubăhathah explained in this article is a good example of intellectual response shown by the Persatuan Islam or commonly abbreviated as PERSIS. Persatuan Islam, together with Muhammadiyah, faces a serious challenge from Salafis. In cities, Salafism has attracted some activists of Muhammadiyah and Persis and even converted them to be Salafis.

The fascination could be caused by the fact that Salafism and reformist organizations share a similar slogan of purification on Islamic doctrines, "the return to the Qur'an and hadith". Having this similarity, Salafi ustadhs have successfully convinced young activists of Muhammadiyah and Persis. Thus, the mubähathah case can be viewed as an effort from the leading figures of Persis to limit and at the same time encounter the influence of Salafism to the adherent and sympathizers of Persis. Through the dialogue, Persis tries to show the weaknesses of Salafism particularly in terms of the arguments. On the other hand, the Salafis have opportunity to examine and dsipute their arguments. Thus, the dialog shows the contest of religious authority between the two parties.[]

\section{Bibliography}

\section{Books and Articles}

al-Thalibi, Abu Abdirrahman. Dakwah Salafiyah Dakwah Bijak. Jakarta: Hujjah Press, 2007.

al-Zarnuji, Imam Burhan al-Islam. Instruction of the Student: The Method of Leaning. Translated by G.E. Von Grunebaum and Theodora M. Abel. New York: King's Crown Press, 1947.

${ }^{21}$ Feillard, “From Handling Water,” p. 168. 
al-Zarnuji, Imam Burhan al-Islam. Ta'lim al-Muta'allim Tariq al-Ta'allum. Surabaya: Benkul Indah, n.d.

Azra, Azyumardi. "Biografi Sosial-Intelektual Ulama Perempuan: Pemberdayaan Historiografi." in Jajat Burhanudin (ed.). Ulama Perempuan Indonesia. Jakarta: Gramedia and PPIM UIN Jakarta, 2002.

Bruinessen, Martin van. "Genealogies of Islamic radicalism in postSuharto Indonesia." South East Asia Research vol. 10, No. 2 (2002): pp. 117-154.

- "Traditionalist and Islamist Pesantren in Contemporary Indonesia." in Farish Noor, Yoginder Sikand, Martin van Bruinessen. The Madrasa in Asia: Political Activism and Transnational Linkage. Amsterdam: Amsterdam University Press, 2008.

Dhofier, Zamaksyari. Tradisi Pesantren. Jakarta: LP3ES, 1982.

Feillard, Andree. "From Handling Water in a Glass to Coping with Ocean: Shift in Religious Authority in Indonesi." in Azyumardi Azra, Kees van Dijk, and Nico J.G. Kaptein (eds). Varieties of Religious Authority. Singapore and Leiden: Institute of Southeast Asian Studies (ISEAS), and International Institute for Asian Studies (IIAS), 2010.

Federspiel, Howard M. Persatuan Islam: Islamic Reform in Twentieth Century Indonesia (Ithaca: Cornell University Modern Indonesia Project, 1970)

Gaborieau, Marc. "Redefinition of Religious Authority among South Asian Muslims from 1919 to 1956." in Azyumardi Azra, Kees van Dijk, and Nico J.G. Kaptein, (eds). Varieties of Religious Authority. Singapore and Leiden: Institute of Southeast Asian Studies (ISEAS), and International Institute for Asian Studies (IIAS), 2010.

Geertz, Clifford. "The Javanese Kijaji: The Changing Role of a Cultural Broker." Comparative Studies in Society and History. Vol. 2, No. 2 (January 1960).

Hoesterey, James B. "Marketing Morality: The Rise, Fall and Rebranding of Aa Gym." in Greg Fealy and Sally White, 
Expressing Islam: Religious Life and Politics in Indonesia. Singapore: ISEAS, 2008.

Horikoshi. Kyai dan Perubahan Sosial. Jakarta: Perhimpunan Pengembangan Pesantren dan Masyarakat (P3M), 1987.

Iskandar, M. et.al. Peranan Elit Agama pada Masa Revolusi Kemerdekaan Indonesia. Jakarta: Departemen Pendidikan Nasional, 2007.

van Bruinessen, Martin. Rakyat Kecil, Islam dan Politik. Yogyakarta: Bentang Budaya, 1998.

\section{Internet Sources}

http://www.muhammadiyah.or.id/id/content-167-det-prof-dr-h-amien-rais.html, accessed on January 2, 2012

http://www.muhammadiyah.or.id/id/content-168-det-prof-dr-ahmadsafii-maarif.html, accessed on January 2, 2012

http://www.muhammadivah.or.id/id/content-169-det-prof-dr-h-m-din-syamsuddin.html, accessed on January 2, 2012. 